\title{
Türkiye'deki Hristiyan Pazarı Değerlerinin Analizi ve İnanç Tabanlı Pazarlama Kapsamında Bu Değerlerin İlgili Pazarlara İletilmesi
}

\author{
The Analysis of the Market Values of Christianity in Turkey and Transferring \\ These Values to Related Markets within the Context of Faith-Based Marketing
}

\section{F. Özlem GÜZEL ${ }^{*}$}

Özet: 12.000 yıllık bir medeniyet tarihine ev sahipliği yapan Anadolu topraklarına gelen topluluklar, kendi kültürel değerlerinin yanı sıra inançlarını da taşımışlardır. Bu durum Anadolu'da, inanç turizmi kapsamında üç büyük semavi din; Müslümanlık, Hristiyanlık ve Yahudiliğe ait önemli ziyaret merkezlerinin zengin varlığıyla sonuçlanmıştır. Özellikle belirli dönemlerde yapılan ibadet ve hac ziyaretleri göz önüne alındığında Türkiye gibi zengin kaynaklara sahip olan ülkelerin turistik ürün çeşitlendirmesi kapsamında bu kaynakları uluslararası platformlarda pazarlaması kaçınılmaz bir durumdur. Bu bağlamda bu çalışmada inanç turizmi pazarı, ekonomik ve turistik açıdan değerlendirilerek Anadolu topraklarında yer alan Hristiyan ibadethaneleri ve çekim merkezleri taranmıştır. Sonuç bölümünde ise inanç tabanlı pazarlama (ITP) faaliyetleri değerlendirilerek İTP ile Hristiyanlık merkezlerine yönelik turist sayısının arttırılması için öneriler sunulmuştur.

Anahtar Sözcükler: İnanç Tabanlı Pazarlama, inanç turizmi, Hristiyan pazarı, Anadolu'daki Hristiyanlık yapilar1

Abstract: Each community brought its beliefs together with its cultural values to Anatolia which has hosted a 12.000-year history of civilizations. Within the context of touristic product diversity, Anatolia presents important centres of the three monotheistic religions, Islam, Christianity and Judaism. Especially for worship and pilgrimage, Turkey has rich resources to market on the international platform. In this study, firstly, the faith tourism market was evaluated within the scope of economics and tourism, then, the centres of Christian worshipping and for shooting were evaluated. Finally, some suggestions were made in the attempt to attract more tourists to centres of Christianity within the scope of faith-based marketing (FBM) activities.

Keywords: Faith Based Marketing, faith/religious tourism, Christian Market, Christian structures in Anatolia

İnsanoğlu var olduğu ilk günden itibaren, bir dine ait olma ihtiyacı hissetmiştir. Bu yüzdendir ki, insanoğlunun dünya üzerinde varoluş tarihine bakıldığında birçok değişik din ve inanç gruplarının ortaya çıktığı görülmektedir. Bu din ve inanç gruplarına ait kutsal yerler insanoğlu tarafindan kitlesel hareketler ile ziyaret edilmiştir (Güzel, 2010, 90). Horner, \& Swarbrooke (1999), inanç turizminin Hristiyanlık öncesi Eski Mısır ve Hellen kültürlerinde de var olduğunu belirtmektedir. Erken dönemlerden itibaren insanların inandıkları dinlere ait çekim merkezlerine giderek orda bulunmak, dini vazifelerini yerine getirmek ve ruhsal açıdan rahatlamak için yaptıkları seyahatler ve konaklamaların turizm kavramı içinde değerlendirilmesine, inanç turizmi denmektedir. Çağdaş hacılar, dualarının daha büyük bir anlam kazanacağını hissettikleri destinasyon arayışları içindedirler (www.ntvmsnbc.com). Bu destinasyonlara yapılan dini

\footnotetext{
* Öğr. Gör. Dr., Muğla Sitkı Koçman Üniversitesi, Ortaca Meslek Yüksekokulu, ozlemmguzel@hotmail.com
} 
seyahatler; turistlerin ruhsal, fiziksel, zihinsel, sosyal ve duygusal noktalarına dokunarak 'içsel rahatlamaya ve huzura' kavuşmalarını sağlamaktadır. İnandıkları dinlere ait merkezi görmek, günahlarından arınarak ruhsal kurtuluşa ermek, manevi huzura kavuşmak, özünü keşfetmek, din kardeşleriyle aynı ortamda bulunarak kendilerini bir grubun parçası olarak hissetmek, dini aktivitelere katılmak ve temel dini vazifelerini gerçekleştirmek; inanç turizminin başlıca seyahat nedenleridir. Woodward (2004), ruhsal seyahat için itici dürtü olarak ailelerarası irtibat kurma (örn. kilise düğünleri), önemli ve ünlü kişileri ziyaret etme (örn. Meryem Ana) ve kilise mimarisine yönelik özel ilgiyi (örn. Ayasofya Kilisesi) göstermektedir. Yılmaz da (2000) insanları inanç turizmine yönelten itici güçler olarak şu nedenleri göstermektedir: dini gereklerden biri olarak hac görevini veya bir adağ1 yerine getirme, şükran göstergesi, sosyal ve manevi yönlerden üstün bir konuma ulaşma, belirli dini olayları kutlama ve anma, aynı dinden olanlarla ilişki ve bağlantı kurma, hakikati (misyon) yayma, konferanslar ve dini toplantılar düzenleme veya bunlara katılma. Destinasyon yöneticileri, bu nedenlerle seyahat eden hacıları çekebilmek için kaynakları doğrultusunda inanç tabanlı pazarlama faaliyetlerini genişleterek ziyaretçi sayılarını artırmalıdırlar.

\section{İnanç Tabanlı Pazarlama}

Din ve turizm arasındaki ilişkinin öneminin anlaşılması için din faktörünün turizm üzerindeki ekonomik ve sosyolojik boyutunun anlaşılması gerekmektedir (Karaman, \& Usta, 2006, 473). İnanç turizmi; yaklaşık 300 milyon ziyaretçiye hizmet veren, 18 milyar dolarlık bir bütçe içeren ve hızla büyüyen bir turizm türüdür (www.religioustravelassociation.com). Örneğin, iklimi ve toprak yapısı tarım ve hayvancılığa uygun olmayan Suudi Arabistan'1n petrolden sonraki en büyük gelir kaynağı, hac vazifelerini yerine getirmek için ülkeye yönelen Müslümanlar olmaktadır. 'Müslümanlar kutsal şehir Mekke'yi ziyaret etmektedir ve bu ziyaretlerden Suudi Arabistan ekonomisi ciddi gelirler elde etmektedir' (Woodward, 2004, 173). Dünyanın farklı yerlerinden Mekke ve Medine'ye hac ve umre ziyareti yapan 12 milyon kişi kutsal topraklara 2012 yılında 16,5 milyar dolar kazandırmıştır (www.turizmguncel.com). Hristiyanlık temelli inanç turizmi de uluslararası turizm sektörüne gelir getiren güçlü sektörlerden birisidir (Woodward, 2004, 173). 6 milyara yaklaşan dünya nüfusunun yaklaşık 1,5 milyarı Hristiyanlığa inanmaktadır. Avrupa'nın \%90'nı bu dinin mensubudur (Sarıkçığlu, 2011, 247). Amerika'da halkın \%77'si (231 milyon) kendisini Hristiyan olarak tanımlamaktadır ve bu oranın \%40-45'i (140 milyon) düzenli olarak haftalık ibadetleri için kiliselere gitmektedir (Stiestra ve Hutchins, 2009). İngiltere'deki 61 katedralin her y1l 19 milyon ibadetçi çektiği tahmin edilmektedir (Woodward, 2004, 173).

Wright'e (2008) göre, ekonomik açıdan hızla büyüyen inanç pazarı seyahat ve konaklama endüstrisinin tüm alanlarını etkilemektedir. Tur operatörlükleri, gemi işletmeleri, oteller, toplantı organizasyon şirketleri, otobüs işletmeleri, turizm danışmanlık şirketleri elde ettikleri gelirler ile hızla ilerleyen bu pazarda önde gelen iş kolları olmaktadırlar. Ayrıca bir internet sitesinde yer alan yazıya göre, konaklama ve ulaşım için harcanan seyahat harcamalarının yanı sıra hac merkezlerinde önemli bir hediyelik eşya pazarı da oluşmaktadır. Örneğin Müslüman Türk vatandaşları, hac dönüşlerinde yakınları için genellikle; Kur'an-1 Kerim, yüzük, tesbih, seccade, misvak, kına, sürme, zemzem suyu, hurma gibi hediyelik eşyalar almaktadırlar ve satıcıların gözdesi olan Türkler, yakınlarına dağıtacağı hediyeler için ortalama 200-1.000 TL. arasında harcama yapmaktadırlar (www.kutsaltopraklar.net). İnanç turizminin ekonomik getirisini göz önünde bulunduran Wright (2007), inançlı insanların harcama alışkanlıklarını değiştirerek birinci sınıf ürünler ve servisler satın almaları dolayısıyla işletmelerin/destinasyonların bir an önce bu güçlü pazarı 'paraya dönüştürülebilir sermayeler' olarak kullanmaları gerektiğini vurgulamaktadır. İnanç tabanlı pazarlama üzerine araştırmalar yapan Stielstra, \& Hutchins (2009); Time Life, General Motors gibi şirketlerin ve politikac1ların (George Bush- 
2004 seçimleri örneği) seçim zamanlarında inanç tabanlı iletişim faaliyetlerini kullandıklarını belirtmektedir. 2008 yılında ABD başkan adayları, halkı dini açıdan etkileyebilmek için milyon dolarlar harcamıştır. Mel Gibson'ın İsa'nın Çilesi adlı filmi sonrasında işletmeler, özel ürün bekleyen Hristiyan tüketicilerin farkına vararak inanç tabanlı pazarlama faaliyetlerine yönelmişlerdir. Söz konusu film, afişler kullanılmadan sadece özel davetler ile, ilk 9 haftasında 551 milyon dolar hasılat elde etmiştir. Ek yan satışlarla Mel Gibson'ın toplam kazancının 700 milyon dolar civarında olduğu tahmin edilmektedir. Ayrıca film, yıllık 4,2 milyar dolarlık satış yapan ABD dini eserler endüstrisini de vizyona girerek hareketlendirmiştir (www.milliyet.com.tr). Başarılı yaşam için Allah'ın beş önerisini sunan The Purspose Driven Life kitabı ise, üç yılda 30 milyon kopya satarak Harry Potter gibi kitapların satış hızını geçmiştir (Stielstra, \& Hutchins, 2009). Bu örneklerde görüldüğü gibi insanların dinsel bağlılıkları gerek işletmelerce gerekse politikacılar tarafından bir pazarlama aracı olarak kullanılmıştır. Bu bağlamda özellikle ikna yöntemlerinde ve iletişim araçlarında inanç tabanlı pazarlama faaliyetlerinden yararlanılmıştır ve 'neden İTP faaliyetleri doğrudan amacına hitap etmesi için turizmde kullanılmasın' sorusu ortaya çıkmıştır. Çünkü Dini Konferans Birliği Başkanı Wright'e (2007) göre, özellikle son 30 yıldır büyük gelişmeler gösteren inanç turizmine katılanların sayısı 1994'den 2006'ya kadar olan kısa bir dönem içinde 4,4 milyon katılımcı sayısından 14,7 milyon katılımcı sayısına erişmiştir ve inanç tabanlı pazarlama faaliyetlerini kullanan işletmeler/destinasyonlar, müşteri/ ziyaretçi sayılarını giderek artıracaklardır.

İnanç turizmi pazarını analiz eden Hughey (2008), İsrail'in inanç turizminde ilk sırada olduğunu, İsrail'i sırasıyla İtalya, İngiltere, İrlanda, Mısır ve Yunanistan'ın takip ettiğini, turistlerin üçte birinin grup şeklinde yolculuk yaptığını, 8-14 gün arasında konakladıklarını ve 1.500-3.000 dolar arasında harcama yaptıklarını belirtmektedir. Wright da (2007), Vatikan yetkililerinin yaptı̆g ziyaretlerin ziyaret edilen destinasyonlara yönelik hac ziyaretlerini artırd1ğını, Kudüs ve İsrail gibi kutsal toprakların ziyaretçi bakımından yeni yüzyılda rekorlar kırdığını ve kruvaziyerlerin özellikle bahar aylarında din seyyahlarınca tercih edilen bir ürün haline geldiğini belirtmektedir.

Wright (2007), inanç turizmi pazarını '12 bölüme' ayrılmaktadır. Bunlar: Hac yolculuğu, misyonerlik seyahatleri, gemi yolculukları, duygu paylaşımı seyahatleri, konferanslar/kongreler, inanç destinasyonu/dinsel etkinlik meraklıları, inzivaya çekilme/misafir evleri, Hristiyan kampları, macera/aktivite severler, yardım amaçlı gönüllü seyahat eden dini birlikler, din okullarında eğitim gören öğrenciler/gençler, aile ziyaretleridir. Karaman ve Usta’ya (2006) göre; dini yapılar, ayinler, dini festivaller, inançlar ve dinsel olaylar turist davranışlarını etkileyen ve turistleri inanç turizmine yönelten önemli faktörlerdir. İnanç Konferans Yönetimi Birliği’ne göre; 2006 yılında 15 milyon kiși, 17.000 dini toplantıya katılmıștır. Dünya Gençlik Günü, ortalama 1 milyon katılımcıyı ve Ulusal Vaftizciler Kongresi yaklaşık 50.000 katılımcıyı çekebilmektedir. Hristiyan müzik festivalleri ise y1llık ortalama 500.000 katılımcı çekmektedir (Wright, 2007). Stielstra \& Hutchins (2009), inanç tabanlı pazarlama kapsamında özellikle işletmelerin müşteriye ulaşmak için uyguladığı bazı yöntemlerden bahsetmektedirler. Bunlardan bazıları yerine;

- Yerel din kuruluşları adına yapılan golf turnuvaları vb. aktivitelere sponsor olmak,

- AIDS yürüyüşü düzenlemek,

- Hapishanedeki Hristiyanları hediyeler vermek için ziyaret etmek,

- Dini gençlik gezileri ve spor kampları organize etmek, gibi yöntemlerdir.

$\mathrm{Bu}$ yöntemler destinasyon yöneticilerine de fikirler sunmaktadır. Pazarlama iletişimi açısından ise Stielstra, \& Hutchins (2009), yine ağızdan ağıza iletişim, radyo, TV, gazete/dergi, çevrimiçi strateji, izinli pazarlama, doğrudan pazarlama ve etkinlik pazarlamanın doğrudan Hristiyan pazarları için kullanılabilecek araçlar olduğunu belirtmektedirler. 


\section{Türkiye'deki Hristiyanlık Değerleri}

Gerek antikçağ medeniyetlerinin Anadolu'da gelişmesi gerekse Hristiyanlığın ilk dönemlerinde havarilerin, yeniçağda ise Musevilerin bulundukları ülkelerde karşılaştıkları ağır baskı ve yok etme politikaları sonucu, bu topraklara sı̆̆ınmış olmaları Türklerin kendi dini olan İslamiyet'e ait eserlerin yanı sıra bu durum antikiteden itibaren çok sayıda sinagog ve kilisenin Anadolu'da yer almasına neden olmuştur (www.kultur.gov.tr). Dünyada İslam ve Hristiyanlık inancına sahip yaklaşık üç milyar insan yaşamaktadır. Kültür ve Turizm Bakanlığı, turizmi zaman ve mekân boyutunda yaygınlaştırmak amacıyla başlattığı İnanç Turizmi Projesi ile 43 ilde 167'si İslam, 129'u Hristiyan ve 20 tanesi Musevi dinine ait toplam 316 eser tespit etmiştir (www.kobifinans.com.tr). İslami anlayış paralelinde derin sayg1 ve hoşgörü içerisinde günümüze kadar ulaşan bu eserler, Türkiye'yi diğer ülkelerden daha avantajlı duruma getirmektedir (www.kultur. gov.tr). Türkiye'deki istatistikler, Amerikalı turistlerin Türkiye'yi ağıllıklı olarak inanç turizmi kapsamında tercih ettiğini ortaya koymaktadır ve Avrupalı bir turist ortalama 700 dolar civarında döviz girdisi sağlarken Amerikalı bir turist bu miktarın iki katını sağlamaktadır (www.pazarlamaturkiye.com). Sadece Amerika'daki düzenli olarak ibadetlerini yapan 140 milyonluk büyük pazar Türkiye'deki ibadethanelerle ilişkilendirildiğinde, Türkiye'nin turist sayısının artış yapması beklentisinin 'ütopik' bir beklenti olmadığı düşünülmektedir. Anadolu toprakları üzerinde Hristiyan dünyası için önemli olan birçok merkez bulunmaktadır. Hristiyanlık için önemli olan bu yerlerden bazıları Vatikan ve Papa gibi resmi Hristiyan görevlilerce hac yerleri olarak ilan edilmiştir.

Hristiyanlık tabanlı inanç turizminin en önemli değeri olan Hz. İsa, bugünkü gibi karışıklıklar içinde olan Filistin topraklarında doğmuştur. Bu topraklar Roma İmparatoru'nun atadığı Heroin tarafindan yönetilmekteydi. Hz. İsa'nın doğduğu dönemde dört önemli Yahudi cemaati (Ferisiler, Saddukiler, Esseniler, Nasuriler) bulunmaktadır. Yuhanna'nın ihanetiyle yakalanan Hz. İsa Golgota Tepesi'nde çarmıha gerilmiştir. Hristiyanlar, Hz. İsa'nın çarmıha gerilişinden üç gün sonra dirildiğine ve mucizevi bir şekilde havarilerine göründüğüne inanmaktadır. Hz. İsa'nın havarilerine ve öğrencilerine görünerek "Dünya'ya gidin ve tüm yaratılışa müjdeyi duyurun" dediği rivayet edilmektedir (Olgunlu, 2005). Bu olayın ardından Anadolu toprakları, Hristiyanlığın şekilleneceği bir merkez olmaya başlamıştır. Hz. İsa'nın havarileri, Anadolu topraklarından başlayarak dünyaya Hristiyanlığ 1 yaymak için yolculuklara başlamışlardır. Ek olarak havari kelimesi; 'seçilmiş, kusursuz' anlamına gelmektedir. Hz. İsa havarilerini kendisi seçmiştir. 12 havarinin isimleri şöyledir: Petrus, Andreas, Yakub, Küçük Yakub, Yuhanna, Filipus, Bartalamous, Taday, Matta, Simon, Goya ve Yahuda. Yahuda'nın Hz. İsa'ya ihanet etmesi sonrasında Mattias havariliğe alınmıştır (Olgunlu, 2005).

Antakya'da bulunan Aziz Peter Kilisesi, dünya üzerindeki ilk kilisedir. Kilise, Hz. İsa'nın 12 havarisinden biri olan Aziz Peter'in Hz. İsa'nın ölümünden sonra Hristiyanlığı yaymaya çalıştığ yer olarak önemli bir dinî merkezdir. 1963 yılında Papa VI. Paul tarafindan hac yeri olarak ilan edilmiştir. Her sene 29 Haziran günü burada törenler düzenlenmektedir (www.kultur.gov.tr). Bu kilisenin diğer bir önemi ise Hz. İsa'ya inanan insanlar için kullanılan 'Hristiyan' kelimesinin ilk olarak bu kilisede kullanılmış olmasıdır. Bir başka havari olan Yuhanna, İncil'inin bir bölümünü Urfa yakınlarındaki Rumkale'de yazmış ve Efes'te bitirmiştir. Hz. İsa çarmıhta iken annesi Hz. Meryem'i Yuhanna'ya emanet etmiş ve Aziz Yuhanna, Hz. Meryem'i Kudüs'ten Efes'e getirmiştir (Olgunlu, 2005) ve M.S. 42-48 tarihleri arasında Efes'te yaşamışlardır. Ancak Aziz Yuhanna, Traianus M.S. 99-117 zamanında şehit edilmiştir. M.S. II. yüzyılda Ayasuluk Tepesine Yuhanna Kilisesi yapılmıștır. VI. yüzyılda da kilise yerini büyük bir bazilikaya bırakmıştır ve Yuhanna'nın mezarı da bazilikanın orta kubbesi altındadır (Yenen, 2007). Selçuk'ta, Efes Antik Kentinin hemen yanı başında bulanan, Meryem Ana'nın kaldığına inanılan Meryem Ana Evi, 1967 yılında Papa VI. Paul ve 1979 yılında Papa II. Jean Paul tarafından ziyaret edilmiştir. 
Vatikan tarafından kutsal ilan edilen Meryem Ana Evi, dünyanın dört bir yanından gelen Hristiyanların ziyaret ettiği, gözde bir kutsal merkezdir. (www.meryemana.net). Hz. İsa'nın 12 havarisinden taşlanarak şehit edildiğine inanılan Aziz Filipus'un öldürüldüğü/gömüldüğü ve M.S. V. yüzyılda anıt mezarının yapıldığı yer Pamukkale'de bulunan Hierapolis Antik Kentidir.

Dört İncil yazarından birisi olan Yuhanna, vahiy kitabında Hz. İsa'nın yeniden dirilişinden sonra dünyada olacak felaketlerden bahsetmektedir. Bu vahiy kitabında Küçük Asya'daki yedi kiliseden bahsedilmektedir (Olgunlu, 2005). Söz konusu yedi kilisenin hepsi Anadolu'da bulunmaktadır: Laodikeia/Goncalı (Vahiy, 3, 14-22), Efes (Vahiy, 2, 1-7), İzmir (Vahiy, 2, 8-11), Sardes (Vahiy, 3, 1-6), Bergama (Vahiy, 2, 12-17), Alaşehir (Vahiy, 3, 7-13) ve Akhisar (Vahiy, 2, 18-29). Bu kiliseler, hem Aziz Paulus'la hem de vahiylerle ilişkilidir. Bunlar M.S. 95'te yedi kiliseye Aziz Yuhanna tarafından yazılmış mektuplardır. Bu kiliselerle kentlerde bulunan cemaat kastedilmektedir. Çünkü özgün kiliseler, 3. yüzyıla kadar yapılmamıştır ve bu tarihe kadar cemaat toplantıları evlerde gerçekleştirilmiştir (Yenen, 2007).

Hristiyanlıkta kilise önderleri ve ileri gelenlerinin dinsel öğreti ve kuralları görüşüp karara bağladıkları toplantılara 'konsil' adı verilmektedir. Bir konsilin ekümenik sayılması için bütün piskoposların bu toplantılara katılması gerekmektedir. Miladın ilk bininci yılında sekiz evrensel konsil düzenlenmiştir ve bu evrensel konsillerin hepsi de Anadolu topraklarında gerçekleştirilmiştir (www.hristiyan.net). Bu toplantılar Anadolu'da; birincisi İznik'te, ikinci ve üçüncüsü Efes'te, dördüncüsü Kadıköy'de, beşincisi ve altıncısı İstanbul'da ve yedincisi Bergama'da olmak üzere gerçekleştirilmiştir. M.S. 325 yılında I. Constantinus tarafindan toplanan ve ilk ekümenik konsil olan İznik (Nikaia) konsili, Hristiyan Ortodoksluğunun ilk dogmatik açıklaması olan Nikaia Amenti ve imparator-kilise arasındaki ilişkinin açıklığa kavuşması açısından önemlidir. 7. ekümenik konsil olan ve İmparatoriçe İrene tarafindan M.S. 787 yılında toplanan konsil ise aziz imgelerinin ve ikonların dinsel tapınım olarak kullanılma kurallarının belirlenmesi amacıyla gerçekleştirilmiştir (Yenen, 2007). M.S. 431 yılında Efes de 3. ekümenik konsile ev sahipliği yapmıştır. Bu konsilde Meryem Ana'nın Tanrı'nın annesi (Theotokos) sayılıp sayılmayacağı tartışılmıştır. Olaylı geçen konsil toplantısında; Hz. İsa'da Tanrı ve insan olarak iki tabiatın varlığı ve Meryem'in theotokos, yani Tanrı'nın annesi olduğu (Yenen, 2007) ve hakiki Tanrı'y1 doğurduğu görüşü (Sarıkçığlu, 2011) ilan edilmiştir. Mesih'in iki tabiata sahip olduğu görüşü, zihinlerde soru işareti oluşturan bir konuydu. Tanrı'nın insan olduğu sırrı, Monofizitler (bu görüşe göre, Hz. İsa kelam ile birleşmeden önce Tanrı'dır ve dolayısıyla Hz. Meryem Tanrı annesidir) ve Nesturilerin ('diofizit' olarak da adlandırılan bu görüşe göre Hz. Meryem insan olan Hz. İsa'nın annesidir ve Hz. İsa kelam ile birleştikten sonra tanrılık vasfını kazanmıştır) itirazına uğramıştır ve 451'de Kadıköy'de bir konsil gerçekleşmiştir (Sarıkçığlu, 2011). Kadıköy konsillerini İstanbul ve Bergama konsilleri takip etmiştir.

Günümüzde inanç önderlerinin emrettiği yerler dışında, belirli zamanlar içinde yaşamış ve bu dünyadan göç etmiş fakat önemi daha sonradan ortaya çıkmış kıymetli şahsiyetler de kültür elçisi olmuşlar ve böylece inanç turizminin çerçevesi genişlemiştir (Açıkel, 2000). Hristiyanlarca Noel Baba olarak bilinen ve sevilen Aziz Nikolaos Likya'nın altı önemli şehrinden birisi olan Patara'da doğmuş, dini eğitimini Filistin ve Mısır'da tamamlayarak yurduna dönmüş ve Myra Hristiyan kilisesinin piskoposu olmuştur (Olgunlu, 2005). Fakir bir ailenin evinin bacasından ardı ardına gelen senelerde üç kez altın kesesi atması ile ünlenen Aziz Nikolaos, 6 Aralık'ta 'Noel Baba' kutlamalarında hediye verme biçimiyle Hristiyanlarca uygulanan bir geleneğe temel oluşturmuştur (Yenen, 2007). XI. yüzyılda, öldükten sonra gömüldüğü yere gelen İtalyan gemiciler, Aziz Nikolaos'ın mezarını açarak kemiklerini Bari'ye götürmüşlerdir. Geride kalan çene kemiği ve kafatası gibi iskelet parçaları Antalya Arkeoloji Müzesindedir. Aziz Nikolas'ın gömüldügü yerin üzerine inşa edilen kilise ile ünlenen Demre'de her yıl 6 Aralık'ta ayinler yapılmaktadır. Günümüzde kırmızı kıyafetli, ak sakallı dede görüntüsüyle bağdaştırılan Aziz Nikolaos, 
Noel Baba olarak anılmaktadır.

İbranice adı Saul olan Aziz Paulus (Aziz Paul/Pavlos), ilk Hristiyan hareketinin lideridir ve Hristiyanlığın Greko-Romen dünyasına yayılmasına katkıda bulunmuştur (Yenen, 2007). Hristiyan dünyası 12 havari haricinde, Aziz Paulus'u da önemsemektedir. Başlangıçta fanatik bir Yahudi olan Paulus, kendi ifadesiyle Hz. İsa'nın ona görünmesi ve çağrıda bulunması üzerine Hz. İsa dininin kurucusu olmuştur (Olgunlu, 2005) ve Tarsus doğumlu Aziz Paulos, Hristiyanlığ 1 tanıtmak ve yaymak amacıyla önemli gezilerini Anadolu'da yapmıştır. Aziz Paulus'un doğduğu ve yaşadığı ev olarak bilinen yapının ortasında bulunan su kuyusu, bazı Hristiyanlarca hacı olmak için Kudüs'e gitmeden önce ziyaret edilen önemli bir inanç merkezidir. Paulus'un ve Barbanas'in bir sinagogun altında gizlice ilk vaazlarını verdikleri Yalvaç da Hristiyan dünyası için önemli olan bir diğer merkezdir. Hristiyanlığın serbestleşmesiyle sinagog, Paulus adıyla kiliseye çevrilmiştir ve burası Paulus adına kurulan ilk kilisedir. Aziz Paulus'un öğrencisi ve ona inanan ilk kadın olan Aya Tekla'nın yaşamının son yıllarını Silifke'deki mağaralarda geçirdiğine ve yöre halkına Hristiyanlığı yayıp mucize yarattığına inanılmıştır. Ölümünden sonra Aya Tekla Kilisesi Hristiyanlarca 'şehitlik' olarak kabul edilmiş ve 'hac merkezi' olmuştur (www.kultur.gov.tr). Hristiyan dünyası için önemli olan diğer isimler; Roma imparatoru Büyük Constantinus'un annesi Azize Helena, İzmit doğumlu Azize Barbara, İzmir Piskoposu Aziz Polikarpos, Aziz Yorgos ve Aziz/Azize Onorhorios'tur. Azize Helena; İstanbul'un kurucusu olan, M.S. 316'da tüm dinlere serbestlik hakk1 getiren Constantinus'un annesidir. Hz. İsa'nın çarmıhını alıp İstanbul'a getirir. Bu haç kiliselerde Helena ve Constantinus arasında resmedilir. Zulmedilen Hristiyanları kurtardıkları için ölüm döşeğinde Hristiyan olan Constantinus aziz ve annesi azize mertebesine yükseltilmiştir. Tahmini olarak M.S. III. yüzyılda yaşamış olan Azize Barbara da İzmit doğumludur. İzmit valisi olan babası, yaşadıkları dönemde Hristiyanları ölümle cezalandırmaktadır. Kızının Hristiyanlığı benimsediğini öğrendiğinde ise babası, kızını ölüme mahkum eder. Öldürülmek üzere götürülen Barbara'nın bir elinde şarap, bir elinde ise ekmek bulunduğu söylenir. Barbara böylece, bedenimle ve kanımla Hz. İsa gibi ölüme gidiyorum mesaj1 vermektedir (Olgunlu, 2005). Ejderha öldürdüğü efsanesiyle, Hellen tanrısı Herakles'in özellikleriyle bağdaştırılan Aziz Yorgos, kiliselerde hep at üzerinde mızraklı savaşçı şeklinde resmedilmektedir.

Yüzyıllar boyunca dünyanın en büyük kilisesi olan Ayasofya (Hagia Sophia/kutsal bilgelik); Londra'daki Aziz Paulus, Roma'daki Aziz Petrus ve Milano'daki Duomo'dan sonra gelen en büyük kilisedir (Yenen, 2007). Bizans İmparatoru Iustinianus, Ayasofya'y1 M.S. 532-537 tarihleri arasında Hristiyanlık inancını bütün dünyaya göstermek için yaptırmıştır (Sarıkçığlu, 2011). İstanbul'un fethiyle camiye çevrilen kilise, Mustafa Kemal Atatürk'ün emriyle müzeye çevrilerek ziyarete açılmıştır. Muhteşem Ayasofya, dünyanın yüzölçümü bakımından dördüncü büyük katedrali olarak kabul edilmektedir. Yine İstanbul'da olan bir diğer Hristiyanlık eseri ise Kurtarıcı İsa'ya adanmış olan Kariye Müzesi'dir. Ortodoksların merkez patrikhanesi de İstanbul'da bulunmaktadır. Bu patrikhane Fener Rum Patrikhanesi'dir. Bu patrikhane ile birlikte İstanbul M.S. IV. yüzylldan itibaren Ortodoksluğun merkezi konumunda olmuştur.

Anadolu'da Hristiyan dünyası açısından önemli olan bir diğer yer ise M.S. II. yüzyılın sonlarında önemli sayıda Hristiyan topluluğunu barındıran Kapadokya Bölgesidir. Bu devirde Kayseri ve Malatya olmak üzere iki önemli piskoposluk merkezi bulunmaktaydı. M.S. III. yüzyılda rahipler bölgeyi, dinî düşünce ve yaşantının canlı merkezi hâline getirmişlerdir. M.S. IV. yüzyılda Kapadokya üç büyük aziz olarak anılan Aziz Basileios, Nysalı Gregor ve Nazianuslu Gregor'un memleketi olarak bilinmekteydi. Bütün Hristiyanlık fikirleri, bu teologlar tarafindan birleştirilerek yeni bir şekil edinmiştir (www.kultur.gov.tr). Göreme Açık Hava Müzesi de bu kişiler sayesinde önemli bir din eğitim merkezi olmuştur. Bu yüzden bu bölgede İncil'den alınmıș birbirinden güzel fresklerle süslü Elmalı, Karanlık, El Nazar, Yılanlı, Kılıçlar, Çarıklı, Tokalı ve Azize Barbara Kilisesi gibi önemli kiliseler, şapeller ve manastırlar bulunmaktadır. 
Ayrıca Kapadokya Bölgesi önemi dolayısıyla sık sık saldırılara ve baskılara maruz kalmıştır. Bu baskılar ve saldırılara karşı Kapadokya'daki Kaymaklı, Derinkuyu gibi yeraltı şehirleri ve Ihlara vadisi gibi yerler Hristiyanlar için elverişli inzivaya çekilme ve korunma yerleri olmuştur. Yine Ihlara Vadisi içinde ulaşılması kolay Ağaçaltı Kilisesi, Yılanlı Kilise ve Sümbüllü Kilise bulunmaktadır. Bir başka dini ziyaret kaynağı ise Eshab-1 Kehf (Yedi Uyurlar) Mağarası'dır. Eshab-1 Kehf Mağaras1, Hristiyan ve Müslümanlarca kutsal bir ziyaret yeri olarak kabul edilmektedir. Türkiye'de 'Yedi Uyurlar' efsanesinin gerçekleştiği söylenen 3 yer bulunmaktadır. Bu yerler; İzmir-Selçuk, Kahramanmaraş-Elbistan ve Mersin-Tarsus'dur. Hatta Bu önemli efsaneye İspanyalılar da sahip çıkmaktadır. Olayın Kurtuba Şehrinde Cinanu'l Verd'de gerçekleştiği iddia edilmektedir.

\section{Sonuç}

Son yıllarda insanların dini vazifelerini yerine getirme arzusu ve manevi huzur arayışlarına yönelmesiyle birlikte inanç turizmi giderek artış gösteren bir turizm şeklini almıştır. Anadolu toprakları jeopolitik konumu ve tarihteki önemi itibarıyla inanç turizmi açısından çok sayıda önemli merkezi bünyesinde barındırmaktadır. Türkiye'de inanç turizmiyle ilgili yapılan ilk ciddi çalışma, 1993’te Kültür ve Turizm Bakanlığı'nın dini-kutsal yerler envanteri hazırlaması ve önemli merkezleri tespit etmesi olmuştur. Türkiye, milyonlarla ifade edilen ziyaretçi sayısına sahip olan inanç turizmi pazarının en gözde merkezlerinden biri olmalıdır. Fakat inanç turizminin geliştirilmesi için inanç tabanlı pazarlama faaliyetlerine de yer verilmelidir. Zengin kaynakları olan Anadolu topraklarında inanç turizminin sağlıklı bir şekilde büyümesi ve ekonomik getirilerinin artırılması için ITTP kapsamında sunulacak öneriler şu şekildedir:

- İnanç pazarına yönelik ciddi ve detaylı analizler yapılarak dini mekanların envanterleri uzman kişilerce çıkarılarak broşürler/materyaller hazırlanmalı ve inanç tabanlı pazarlama faaliyetleri kapsamında gerekli yerlere dağıtılmalıdır. Hristiyanlar, doğrudan kilise ve papazlarla irtibat kurularak ve Christianity Today, Relevant, Preaching Today, Today's Christian Woman gibi dergiler ve dini gazeteler aracılığıyla Türkiye'ye davet edilebilir. Ayrıca Stielstra, \& Hutchins'ın (2009) belirttiği üzere, ABD'nin \%8'i hala radyo kanallarını dinlemektedir ve ülkede az reklam alan ve sınırlı rakip reklam ortamının olduğu Hristiyanlara yönelik özel radyo kanalları mevcuttur. Dinlerine bağlı olan Hristiyanlar bu kanalları dinleyerek desteklemektedir. Yine Stielstra, \& Hutchins'ın (2009), Web 2.0'1n starları olarak adlandırdığı facebook.com, myspace.com, youtube.com, xianz.com (Hristiyan forumu), tangle.com (1.500 Hristiyan organizatörün linkini içeren), tubumogul.com gibi sosyal medya kanalları da kullanılabilir. Tüketicilerin, sosyal medyaya istekli katılımları göz önünde bulundurularak birinci sınıf servis ve ürünleri tercih eden inanç turizmine katılan turistlere yönelik bir internet sayfası oluşturulmalı ve insanların daha hızlı/kolay şekilde Anadolu topraklarındaki hac yerlerine ait bilgilere, fotoğraflara ve videolara ulaşması sağlanmalıdır.

- İnanç turizmi paket ürünleri, inanç turizmi dışında başka ürünler ile desteklenmelidir. Özellikle 3. yaş grubuna hitap eden inanç turizmi, Türkiye'de üretilebilecek yayla turizmi, kırsal turizm gibi diğer turizm türlerine yönelik paket turlarla çapraz satışları desteklenirken diğer paket ürünlerin satışları da artırılabilir.

- Etkinlik pazarlaması kapsamında Hristiyanlık için önemli olan 'festival, konser ve müzikal' gibi faaliyetler ve etkinliklere ev sahipliği yapılabilir. Hac seyahatlerinin yanı sıra milyon dolarlık pazar dilimi olan dini toplantıların, kongrelerin, konferanslar ve inanç kamplarının Türkiye'de yapılması için girişimlerde bulunulmalıdır. Ancak bu aktivitelerin yapılacağı yerler iyi seçilmelidir. Çünkü Türkiye'deki bazı bölgelerde bu turizm türüne sosyo-psikolojik açıdan hazır olunmayabilir. Nitekim Tümbek'in (2009) Antakya'da inanç turizmine yönelik yaptığ 1 araştırmada bölgede inanç turizminin gelişmemesinin nedenlerinden birisi olarak yöre halkının turistlere hoşgörülü davranmaması gösterilmiştir. Yine Hristiyanlık için önemli olan günlerin ve 
bayramların Anadolu toprakları içinde Meryem Ana Evi gibi Hristiyanlık ibadethanelerinde kutlanması için özel programlar hazırlanabilir. Hristiyanlık için önemli olan günler ve şahsi bayramlar şu şekildedir (Olgunlu, 2005):

- Noel Bayramı: 25 Aralık,

- Kutsal Aile Bayrami: Noel Bayramından sonraki ilk pazar günü,

- Epifanya Bayramı: 2-8 Ocak arasındaki Pazar gününde doğudan gelen 3 kahinin anılması,

- Paskalya Bayramı: Hz. İsa'nın çarmıha gerildikten sonraki üçüncü günde yeniden dirilişinin ifadesi,

- Pentikost: Havarilerinin mucize ile tüm lisanları konuşabilme becerisi için kutlanan bayram,

- İsa'nın göğe yükselmesi: Paskalya'dan 40 gün sonra kutlanan bayram,

- 1 Ocak: Meryem Ana'nın ilahi analı̆̆l,

- 25 Ocak: Paulus'un Hz. İsa'ya inandığı gün,

- 19 Mart: Hz. Meryem 'in nişanlısı Yusuf adına bayram günü,

- 25 Mart: Cebrail'in Meryem'e hamileliği müjdelediği gün,

- 9 Haziran: Mardinli yazar ve Şair Efrem 'in bayramı,

- 24 Haziran: Yahya'nin doğum günü,

- 8 Eylül: Meryem Ana'nın doğum günü,

- 1 Kasım: Tüm azizlerin doğum günü,

- 2 Kasım: Ölüleri anma günü.

- İzinli pazarlama kapsamında da daha önce gelmiş olan müşterilerle sürekli iletişim sağlanabilir ve tanıdıklarını davet etmeleri hususunda kendilerine indirimler sağlanabilir. Böylece en etkili promosyon ve reklam aracı olarak ağıdan ağıza pazarlama desteklenebilir.

- İnanç turizmi bakımından rekorlar kıran Kudüs ve İsrail'e giden turistlerin bir şekilde Türkiye'den geçmeleri sağlanabilir. Bu duruma yönelik Hristiyanlığın 'yayılım alanı yol analizleri’ yapılarak, önemli olan diğer ülkelerle ortak yol haritaları çıkarılabilir.

- İnanç turizmi pazarını geliştirebilecek bir oluşumun/yönetimin yaratılması düşünülebilir. Kurulacak olan bu yönetim/oluşum özellikle önemli dinsel seyahat ve toplantılara öncülük eden, inanç turistlerine yol gösteren ve bu sektörde söz sahibi olan Dünya İnanç Turizmi Birliği (WRTA) ile sürekli 'iş birliği' halinde bulunarak davetkâr yaklaşımlar sergilemelidir.

- Kültür ve Turizm Bakanlığı iyi bir pazar araştırması yaparak Amerika'da başlattığı reklam kampanyası gibi projelerle inanç turizmine katılması muhtemel İspanya gibi kalabalık Hristiyan pazarlarına da yönelmelidir. ABD'de yeni düzenlenmeye başlanan Anadolu Festivalleri gibi 'etkinliklerde' özellikle Hristiyanlık merkezlerinin tanıtım faaliyetleri dikkat çekici hale getirilmelidir.

- İnanç turizmi merkezlerindeki işletmelerin yeterliliği incelenerek eksiklikler giderilmelidir. Özellikle bu yerlerde konaklama kapasiteleri artırılarak birinci sınıf ürün ve servisleri tercih eden ziyaretçilerin istek ve ihtiyaçlarını karşılayacak seviyede yeni ve modern işletmeler yapılmalıdır. Tümbek'in (2009), Antakya'da inanç turizmine yönelik yaptığı araştırmada konaklama işletmelerinin yetersiz olması durumu inanç turizminin bölgede gelişmeme nedeni olarak gösterilmiştir. Yine geçtiğimiz yıllarda Aziz Paulus Yılı dolayısıyla Aziz Paulus'un doğum yeri olan Tarsus'a gelecek turistler için yatak kapasitesinin yetersiz kalacağı düşünüldüğü için ziyaretçilerin, Adana ve Mersin'de konaklatılması gündeme gelmiştir. Bu gibi merkezlerdeki konaklama kapasiteleri eski evlerin butik otellere dönüştürülmesi gibi alternatif konaklama imkanları yaratılarak çözülmeye çalışılabilir.

- Stamenkovic, et alii (2009), Sırbistan'da iç turizmin geliştirilmesi için inanç turizminin itici güç olduğunu da vurgulamaktadırlar. Bu bağlamda, sadece Hristiyan ve Musevi dünyasına yönelik önerilerin yanı sıra inanç turizmi kapsamında İslam dünyası ve yerli turistler de unutulmamalıdır. Seyahat işletmelerinin, yerli turistlere yönelik olarak hazırlayacakları, Müslüman dünyası için 
önemli olan yerlere yönelik yeni tur programları ile iç turizm hareketlendirilebilir. Ayrıca inanç turizmi değerlerinin olduğu bölgelerin çoğu yoğun kitlesel turist akışından uzak bölgelerdir. Bu turizm türünün desteklenmesi ile bu bölgelerdeki turizm hareketleri canlandırılabilir.

- Anadolu'daki inanç merkezlerini ziyaret etmeye gelen turistlere daha iyi rehberlik hizmetinin sunulması için profesyonel turist rehberlerine yönelik inanç tabanlı uzmanlık 'eğitimleri' yaygınlaştırılmalıdır.

\section{KAYNAKÇA}

Olgunlu, A. C. (2005). Ana Tanrıça'dan Mevlana 'ya. İstanbul: Karakutu Yayınları.

Karaman, S., \& Usta, K. (2006). "İnanç Turizmi Açısından İznik ve Bir Uygulama Çalışması". III. Balıkesir Ulusal Turizm Kongresi, 473-89. Balıkesir.

Küçük, M. A. (2010). "İnanç Turizmi Açısından Türkiye. Türkiye'de Dinler Tarihi Dünü, Bugünü ve Geleceği”. Ankara: Dinler Tarihi Araştırmaları Dergisi. 7 (7), 755-89.

Horner, S., \& Swarbrooke, J. (1999). Consumer behaviour in tourism. Elsevier.

Hughey, M. (2008). "Religious travel symposium". Leisure Group Travel Special Edition, February, 26-28.

Güzel, F. Ö. (2010). "Turistik Ürün Çeşitlendirmesi Kapsamında Yeni Bir Dinamik: İnanç Turizmi”. Süleyman Demirel Üniversitesi, Vizyoner Dergisi, 2 (2), 87-100.

Sarıkçığlu, E. (2011). Başlangıçtan Günümüze Dinler Tarihi. Isparta: Fakülte Kitabevi.

Stamenkovic, I., J. Plavsa, \& M. Vujicic, (2009). "The New Age of Faith Tourism and Fruska Gora Mountain (Serbia)". Turizam, 13 (2), 102-12.

Stielstra, G., \& B. Hutchins, (2009). Faith-based marketing: the guide to reaching 140 million Christian consumers. John Wiley \& Sons, Inc., United States of America.

Tümbek, A. N., (2009). Bütünleşik Pazarlama Faaliyetleri ile İnanç Turizmini Geliştirerek Yabancı Yatırımın Çekilmesi ve Antakya Örneği. Yayınlanmamış Doktora Tezi. Marmara Üniversitesi, Sosyal Bilimler Enstitüsü İşletme Anabilim Dalı Üretim Yönetimi ve Pazarlama Bilim Dalı. İstanbul.

Yenen, Ş. (2007). Anadolu Destanı: Türkiye Gezi Rehberi. İstanbul: Şan Ofset.

Woodward, S. C. (2004). "Faith and tourism: planning tourism in relation to places of worship". Tourism and Hospitality Planning \& Development, 1 (2), 173-86.

Wright, K. (2007). "Religious Tourism, Leisure Group”. Travel Special Edition, November, 8-16.

Wright, K. (2008). "Religious Tourism, Leisure Group". Travel Special Edition, February, 34-35.

Yılmaz, B. S. (2000). Türkiye'de Dini Turizm ve Meryem Ana Evi'nin Turistik Potansiyelinin Analizi. Yayınlanmamış Yüksek Lisans Tezi. İzmir: Dokuz Eylül Üniversitesi Sosyal Bilimler Enstitüsü.

\section{İnternet Erişimleri}

http://www.kutsaltopraklar.net/bilgiler/alisveris.htm, (13.06.2012).

http://www.ntvmsnbc.com/news/442444.asp, (19.10.2012).

http://www.religioustravelassociation.com, (19.10.2012).

http://www.turizmguncel.com/haber/suudi-arabistan-hac-turizmiyle-2012de-165-milyar-dolar-kazandih12939.html, (14.06.2012).

http://www.kultur.gov.tr/TR/BelgeGoster.aspx?F6E10F8892433CFF679A66406202CCB0AFA4D30516 C5690F, (19.10.2008).

http://www.pazarlamaturkiye.com/content/view/406/116, (19.10.2008).

http://www.kultur.gov.tr/TR/BelgeGoster.aspx?F6E10F8892433CFF679A66406202CCB0199F0C581E7 69F43, (19.10.2008).

http://www.kultur.gov.tr/TR/BelgeGoster.aspx?F6E10F8892433CFF679A66406202CCB07798F3C9FED 8DC6A, (20.10.2008).

http://www.meryemana.net/merye/tr/maria/anaevi.php, (20.10.2008).

http://www.hristiyan.net/anadoludahristiyanlik.htm, (20.10.2012).

http://www.kobifinans.com.tr/tr/sektor/0116/19805/2, (19.10.2008). 
